\title{
A REVISION OF TWO JAPANESE SPIDERS OF THE GENUS PIRATA (ARANEAE: LYCOSIDAE)
}

\author{
By
}

\author{
Hozumi Tanaka \\ Entomological Laboratory, College of Agriculture, University of \\ Osaka Prefecture, Sakai, Osaka, Japan
}

\section{Synopsis}

TAnaka, Hozumi (Entom. Labor., Coll. Agr., Univ. Osaka Pref.) : A revision of two Japanese spiders of the genus Pirata (Araneae: Lycosidae). Acta arachnol., 29:1-2 (1980)

As a result of my examination of the type-specimen of Pirata pirctcides, I confirmed that Pirata japonicus should by synonymized with $P$. piratoides.

When I visited Germany in August of 1977, I had fortunately an opportunity to examine many type-specimens of Japanese lycosid spiders preserved in the collection of "Natur Museum Senckenberg", Frankfurt am Main.

In course of my observation, I was especially interested in the specimen of Tarentula (Pirata) piratoides BöSENBERG et STRAND ${ }^{1)}, 1906$ (SMF-2204) closely related to Pirata japonicus which I described in 1974 as a new species.

As a result of the careful comparison of both specimens, I recognized that $P$. japonicus is doubtlessly identical with $P$. piratoides in all the characteristics, particularly in the shape of the female genital organs, although the specimen of the latter had more or less faded.

In my paper in 1974, I described that the first eye row of $P$. piratoides is longer than the second eye row, as a descriminative point from $P$. japonicus, but I confirmed that the first row is slightly but clearly shorter than the second row in both specimens. Consequently, $P$. japonicus is synonymized with $P$. piratoides.

1) Tarentula (Pirata) piratoides Bös. et STr. is now treated as Pirata piratoides (Bös. et STR.) 


\section{Pirata piratoides (BöSENBERG et STRAND)}

Tarentula (Pirata) piratoides Bösenberg et Strand, 1906, Abh. Senck. naturf. Ges., $30: 318$.

Pirata piratoides: SaIto, 1941, Faun. Nipponica 9(2-2): 125 ; Yaginuma, 1970,

Bull. Nat. Sci. Mus. 13: 667; TANAKA, 1974, Acta arachnol., 26(1): 41.

Pirata joponicus TANAKA, 1974, Acta arachnol., 26(1): 29-31. NEW SYNONYMY.

\section{Acknowledgements}

I wish to express my sincere thanks to Dr. M. GRASSHOFF who permited me to examine precious specimens and provided every convenience for my study, and to Dr. T. Yaginuma who introduced me to Dr. M. Grasshoff and gave me such an opportunity through his good offices. Furthermore I am also indebted to $\mathrm{Mr}$. H. ONO who gave me kind help during and after my stay in Frankfurt.

摘要

著者は，1977年 8 月，西ドィツのフランクフルトにある Senckenberg 自然科学博物館におい て, 月本の Lycosidae のタイプ標本を検する機会を得，とくに著者の発表した Pirata japonicus の近似とした P. piratoides Bös. et STR., 1906 の標本を見ることができ，闭者の比較検討を行 なった。著者はさきに日本のある種を P. piratoides の原記載との比較から，わずかな相異を以 て新種としてP. japonicus を記載発表したが，タイプ標本との比較から，P. japonicus $P$. piratoides とすべての点はおいて一致し，両者は同種であることを確認した。従って，P. japonicus は P. piratoides のシノニムとなる。

\section{References}

Bösenberg, W. \& E. Strand, 1906. Japanische Spinnen. Abh. Senck. naturf. Ges., $30: 93-442$.

SAITO, S., 1941. Suborder Arachnomorphae. Tetrasticta Trionycha I. (ArachnoideaAraneina). In Okada et al.: Faun. Nipponica 9(2-2):1-14+1-220. Sanseido, Tokyo. TANaKa, H., 1974. Japanese wolf spiders of the genus Pirata, with descriptions of five new species (Araneae: Lycosidae). Acta arachnol., 26(1) : 22-45. 